ROCZNIKI TEOLOGICZNE

Tom LXVII, zeszyt $1-2020$

DOI: http://dx.doi.org/10.18290/rt20671-8

TETIANA YABLONSKA
LILIA SIROKHA

\title{
THE PECULIARITIES OF CAREER CRISES OF LAWYERS: PSYCHOLOGICAL AND SOCIAL ASPECTS
}

\begin{abstract}
The article deals with the phenomenon of professional crisis of lawyers. The emotional burnout as its manifestation is examined; the importance of detection and psycho-correction of this phenomenon is emphasized. In all the modern democratic developed countries, one of the priorities is to ensure high standards of labor and quality social protection. That is why studying the phenomenon of career crisis can help to improve working conditions and professional development.

Professional life is an integral part of human life, it is one of the important vectors of personality development, and it is a special form of person's socialization. The peculiarity of the professional activity of lawyers is high social responsibility, normativity, and a considerable number of conflict and stressful situations. Difficult conditions of professional activity affect the psychological state of employees, which can cause stress and emotional burnout and even career crisis.

The social and psychological factors of career crises of legal professions were revealed on the basis of empirical research, especially the level of emotional burnout. Features and manifestations of emotional burnout of male and female lawyers, as well as the role of gender stereotypes, were analyzed. Also the role of gender stereotypes in professional activity, which is a significant factor in women's career crisis, is analyzed. The importance of activities to prevent career crises of legal professions is emphasized.
\end{abstract}

Key words: career crisis; emotional burnout; legal professions; psycho-correction; social support; prevention.

\section{INTRODUCTION}

In modern dynamic information society, professional activity is significantly complicated by increasing demands on workers, the complexity of the

Tetiana YABlonsKa - Doctor of Psychology, Professor, Taras Shevchenko National University of Kyiv; address for correspondence: Volodymyrska str., 64/13, Kyiv, Ukraine, 01601, e-mail: t_yablonska@ukr.net

LiLia SiroKHA - PhD student at the Department of Developmental Psychology, Taras Schevchenko National University of Kyiv, address for correspondence: Volodymyrska str., 64/13, Kyiv, Ukraine, 01601, e-mail: lilia-d@ukr.net 
tasks, the increase in the volume of work being done. This is often the reason of the stress and career crises. That is why the problem of studying the peculiarities of career crises and the factors of their occurrence is of great current interest nowadays. Especially it is very acute due to the need to develop ways of preventing and overcoming such crises.

Different professions differ in their characteristics, which can potentially cause crisis. First of all, we are talking about the level of complexity and stress. Legal activity is a component of social activity in society. It has its own specificity and it can be characterized by a high level of stress. At the same time, the lack of research about peculiarities of the professional activity of lawyers makes it relevant to study them, their psychological and social aspects. Especially it is important for ensuring the success of the law enforcement reform process that is ongoing in Ukraine today.

The purpose of the article is to study the peculiarities of the career crisis of employees of the legal professions, in particular its psychological and social factors.

Such research questions were stated as: What are the peculiarities of the professional crisis of workers of the legal professions and what are the main reasons of them? Does the severity of emotional burnout differ as one of the main manifestations of the career crisis of men and women working in the legal sphere? Are gender stereotypes and gender inequalities important factors of the career crisis of women working in the legal sphere?

\section{RESEARCH METHODS}

The test of V.V .Bojko, ${ }^{1}$ which determine the level of emotional burnout and the authorial questionnaire aimed at identifying gender stereotypes in professional activities were used in the research. The questionnaire included the following questions: Have you ever felt biased attitude at your working place due to your gender? In your point of view, can the gender influence any business success? Did you feel any biased attitude from your management when they were evaluating your work, due to your gender? Do you think that men and women suffer from the gender stereotypes and norms that exist in our society? According to your point of view, do you think that men and women work with equal efficiency and results?

\footnotetext{
${ }^{1}$ V.V. BOJKO, Sindrom «emotsyonalnogo vyhoranyia» v professyonalnom obshchenii. 2-e izd. (SPb.: Sudarynia, 2001).
} 
Also such methods of mathematical statistics were used as: $\chi^{2}$-test, Mann-Whitney U-test for comparing samples. The sample group consisted of 68 practisers in the legal field (lawyers, forensic experts, judicial staff), including 26 men and 42 women, aged from 29 to 40 years, with at least 5 years' working experience.

\section{ACTUAL SCIENTIFIC RESEARCHES AND ISSUES ANALYSIS}

Personal development in the profession is a lifelong process. It begins from the moment of career choice and longs till the termination of working life. At the same time, the professional life of a person depends on many factors, which include age, social and individual psychological factors and so on. The following stages are distinguished in the process of professional development as: option, vocational education and training, professional adaptation, primary and secondary professionalization, skill, ${ }^{2}$ as well as career crises, which often occur when person goes from one stage to another.

During defining the term "professional crisis," many researchers argue that the crisis (from gr. Crisis - the solution, the turning point, the exit) is caused by a problem, which a person faces and which he cannot avoid or resolve in a short time and in his usual way. So, we can say that a crisis is a situation when a person cannot fulfill his certain internal needs (motives, aspirations) due to external circumstances, even using all his past life experiences. Crisis is an important, often turning point in a person's life. Besides, it can have not only destructive character but it can also play a constructive role for the future.

Regulatory and non-regulatory crises are usually distinguished in. psychological researches. Despite various interpretations of normativity, it is mostly understood as a certain statistical norm or characteristic of the normal process of development, unlike pathological process. ${ }^{3}$

Researchers often emphasize the similarity of age and career crises when considering regulatory and non-regulatory crises, in particular:

- Regulatory crises are the crises of mental development, as well as the crises of professional formation. Age crises are regulatory because they are necessary for the normal psychological development of a person. Regulatory

${ }^{2}$ Y.A. KLIMOv, Psihologia professionala. M.: Instytut prakticheskoi psyholohii (Voronezh: MODEK, 1996), 400.

${ }^{3}$ I.S. Kon, "Postojanstvo v izmenchivosti," Psiholohycheskij zhurnal (1987), 8, 4: 126-137. 
crises of professional development accompany the transition from one stage to another. They are logically predetermined by the process of professionalization of the individual (for example, the crisis of career choice).

- Non-regulatory crises are the crises, which are related with certain events (such as disability, migration, etc.). Usually, such crises destroy the process of professional development of the individual. ${ }^{4}$

Also we can highlight the extra-regulatory crises that can appear from the manifestation of strong emotional and willpower efforts of the individual (self-termination of training, change of profession, etc.).

Career crises can be caused either by subjective, internal or by external factors, such as: above norm activity due to dissatisfaction with their position or social status; social and economic conditions of life of the individual (job losses, liquidation of the enterprise, change of residence); age-related psychophysiological changes (sickness, reduction of working capacity); obtaining a new position, certification procedure; changes in life (change of place of residence, career break). ${ }^{5}$ So, that is why social (working conditions) and psychosocial factors (social expectations and stereotypes, employee relationships) are quite important along with the psychological factors of the career crisis. Most often, a crisis is the result of a process that has been going on for a long time or the simultaneous effect of several factors.

The psychological crisis, including the professional one, can be characterized by certain subjective dimensions. Such scientist as V.M. Zaika understands the subjective model of crisis as a set of such levels as: 1) sensitive, based on human feelings; 2) emotional, associated with different types of response to individual symptoms of crisis, or to the crisis in general and its consequences; 3 ) intellectual, which is the result of the representation of its condition, reflections on its causes and possible consequences; 4) motivational, related to a certain attitude to their crisis state, or related with changing behaviors and lifestyles during crisis and activity to overcome it. ${ }^{6}$

Career crises have negative manifestations and consequences, including professional burnout syndrome. Professional burnout syndrome it is a state of physical and emotional exhaustion, which can be characterized with the development of negative self-esteem, negative attitude to work, loss of

\footnotetext{
${ }^{4}$ E.F. ZEER, Psyholohyia professyi: uchebn. posobye. 3-e izd., pererab. i dop. (M.: Akademicheskyi Proekt, Fond «Mir», 2005).

${ }^{5}$ Ibidem.

${ }^{6}$ V.M. ZAIKA, "Dynamichna model' osobystisnyh transformatsii v umovah podolannia kryzovykh staniv osobystosti," Sotsialna psykholohiia (2009), 1: 69-76.
} 
compassion for another person; it can include also exhaustion reactions, arising from the stress caused by interpersonal communication. ${ }^{7}$

The specificity of legal activity is determined by the social significance of this activity, which is intended for the purposeful use and change of the environment for the benefit of people. ${ }^{8}$ The work of lawyers is extremely different and complex. It has a whole list of features that distinguish it from the work of other professions, particularly:

1) a variety of tasks, when the way of their solution is expressed in the most general form - in the legal norm. Every new case is a new task for the investigator, the prosecutor, the judge, the lawyer, and the solution of which has no template decisions;

2) despite all complexity and diversity, a legal activity is a subject to legal regulation. And of course, it has its impact on the personality of a lawyer who always compares his actions with the rules of law;

3) this activity is a complex open social system because it is integrated into the broad context of the legal system of society. It solves the state's tasks of justice, personal and public security, and the fight against crime. ${ }^{9}$

A qualified lawyer understands the nature and social significance of his profession; he clearly represents nature of legal phenomena; he knows the main problems in a particular area of his activity, he understands their correlation and importance for the correct realization of the law in professional activity. The appropriate professional motivation is formed on this basis. It can include a complex set of needs, interests, ideals and beliefs. Also, a desire for justice, a love of truth, a sense of duty, patriotism and values play an important role in the professional motivation. The motivation of a specialist's personality is very dynamic; it changes under the influence of different external social and subjective-psychological factors. That is why in specific professional circumstances, motivation either consolidates and expands, or begins to dwindle. A professionally important feature of a lawyer is purposefulness. It can be manifested in the desire to serve and uphold justice, to protect the rights and interests of citizens, and to anticipate the content of their activities. $^{10}$

\footnotetext{
${ }^{7}$ L.F. Burlachuk, E.Yu. Korzhova, Psyholohyia zhyznennykh sytuatsij, (M.: RPA, 1998); N. Bulatevych, "Teacher's burnout syndrome: the phenomenology of the process," Polish Journal of Public Health (2017), 127(2): 62-66.

${ }^{8}$ I.V. BryzGHALOV, Yurydychna deontolohiia korotkyi kurs lektsii (K.: MAUP, 2003), 3-te vyd., stereotyp.

${ }^{9}$ N.M. Chernukha, V.S. Ryzhykov, "Profesijna diialnist' yurysta: teoretychni zasady," Trypil'ska tsyvilizatsija (2012), 7: 45-48.

${ }^{10}$ Ibidem.
} 
Almost for all the legal professions, communication is one of the key components, which means communication under legal regulation. Legal (procedural) regulation specifically influences on all participants in communication, giving them special rights and responsibilities and adding a special character to communication. Most legal professions can be characterized by high emotional labor tensions. And most often it is associated with negative emotions, with the need to suppress them, and to postpone the emotional discharge for a rather long period. ${ }^{11}$

Therefore, professional activity in the legal sphere is connected with a high social responsibility. It is often connected with normativity, with risk or with emotional tension, which often causes career crises.

Another important factor in career crises in the legal profession, which we want to highlight, it is social stereotypes, especially gender. Historically, professional activity in the field of law was considered as a field of realization of men. In modern gender-oriented society, attitudes towards women's professional self-realization have changed. However, gender stereotypes still have a significant impact, especially in the traditionally "masculine" spheres of activity, for example as legal sphere.

Ukraine's current legislation corresponds with European norms in the field of women's rights. This is reflected in the Law of Ukraine "On Equal Rights and Opportunities for Women and Men". At the same time, different researches show that there is a gender imbalance in employment. Thus, according to experts, there is a significant gender gap between remuneration of women and men: the average salary of women over the entire history of Ukraine's independence did not exceed $79 \%$ of men's pay. Numerous violations of women's labor rights are recorded during employment and dismissal: more than $40 \%$ of women have faced violations of their employment rights or the labor rights of their members of family, almost one third of women were refused to be hired due to child birth, pregnancy, or having a small child; and $50 \%$ of them were forced to quit for these reasons. ${ }^{12}$

If we compare Ukraine with EU countries, according to statistics of 2015, then we will find out that the average wage rate for men in the EU was on average $16 \%$ higher than for women, and in Ukraine $23.7 \%$ higher. Besides,

${ }^{11}$ V.V. Romanov, Yurydycheskaia psykholohyia. Uchebnyk dlia yurydycheskykh spetsyalnostei VUZov (M.: Yuryst, 2009).

${ }^{12}$ M.M. SKORYK, Henderna dyskryminatsiia u dostupi do pratsi y posluh: otsinka stanu vprovadzhennia Ukrainoiu antydyskryminatsiinykh Dyrektyv Rady YeS. Analitychne doslidzhennia (Kyiv, Biuro sotsialnykh ta politychnykh rozrobok, 2017), 78, https://bureau.in.ua/downloads/ 2017\%20IRF\%20Project_.pdf. 
in Ukraine, compared to the EU countries, practically as low as one half of women are employed on top management positions than men $(38 \% \mathrm{vs} .62 \%$ respectively). ${ }^{13}$

The issue of gender equality, especially with regard to the service of women in the police and internal affairs agencies, is quite urgent for both Ukraine and other countries. According to the statistic of 2008, 20-40\% of law enforcement officials in the EU countries were women, but in Ukraine only $10 \% .{ }^{14}$ And today, according to various sources, women make up $15-$ $20 \%$ of law enforcement officials in Ukraine, but, as before, most of them do paper work and do not hold management positions.

Ukrainian legislation provides women with equal rights with men when hiring police. ${ }^{15}$ More and more women are working in law enforcement bodies in Ukraine today. Police service has such requirements, that often contradict with traditional stereotypes of female behavior and supports men. In addition, women's career development and career growth are rather difficult, because management and male colleagues have often biased attitudes towards them. Thus, a woman who chooses a career development often faces stresses associated with such attitudes, she usually has the limitation of career advancement, and she can have some difficulties in the combining professional and family roles.

Nowadays scientists are actively studying the problem of combining work, family and other social responsibilities by women working in the legal sphere. The study of social stereotypes of femininity and masculinity and their influence attracts considerable attention of foreign researchers. ${ }^{16}$ A number of studies examine the relationship between gender and 1 values in

\footnotetext{
${ }^{13}$ H.M. YURCHYK, "Dyskryminatsiia na rynku pratsi: proiavy, vitchyznianyi i yevropeiskyi dosvid podolannia," Sotsialno-trudovi vidnosyny: teoriia i praktyka: zb. nauk. pr. M-vo osvity i nauky Ukrainy; DVNZ «Kyiv. nats. ekon. un-t im. V.Hetmana»; In-t sots.-trud. vidnosyn; redkol.: A.M. Kolot (holova) (Kyiv: KNEU, 2016), 2: 118-128.

${ }^{14}$ O.V. RIASHKO, "Zhinka v militseiskomu odnostroi (sotsialno-pravovyi aspekt)," Naukovyi visnyk Lvivskoho derzhavnoho universytetu vnutrishnikh sprav (2008), 3: 1-7, http://www2.lvduvs. edu.ua/documents_pdf/visnyky/nvsy/03_2008/08rovosa.pdf.

15 “Pro Natsionalnu politsiiu Ukrainy: Zakon Ukrainy," vid 02 lypnia 2015 roku № 580-VIII. Vidomosti Verkhovnoi Rady Ukrainy (2015), 40-41: 379. Redaktsiia vid 05.10.2016.

${ }^{16}$ Gender and Judging, ed. by Ulrike Schultz and Gisela Shaw, 2013, 640; E. RACKLEY, "Women, Judging and the Judiciary: From Difference to Diversity" (Routledge-Cavendish, 2012), 232; D. FeEnAn, "Women Judges: Gendering Judging, Justifying Diversity," Journal of Law and Society (2008), 35, 4: 490-519; J. DOHERTY, Women's Representation in Judiciaries Worldwide: Arguments in Favor of Increasing the Gender Diversity on the Bench, 2012, http://www.gwu.edu/ $\sim$ ggi/assets/docs/igis_wp2_ggp_wp1_doherty.pdf.
} 
career choice, ${ }^{17}$ gender and career stereotypes, ${ }^{18}$ the relationship between gender, entrepreneurship and career choices. ${ }^{19}$

So, the career crises of the representatives of legal professions are most often caused by social factors (high social responsibility, difficult working conditions), psychosocial factors (social expectations and stereotypes, relationships with colleagues) and individual-psychological factors and specificity of professional activity.

\section{RESEARCH RESULTS}

As a result of a survey by the method of V.V. Bojko, the severity of emotional burnout was determined, which is a mechanism of psychological protection. It consists in the total or partial exclusion of emotions in response to some psycho-traumatic factors. Emotional burnout is a dynamic process and occurs in stages, forming into certain phases. This syndrome negatively affects the quality of professional activity and is a signal of psychological distress of the employee. ${ }^{20}$ The table 1 presents data on the manifestations of emotional burnout of lawyers, taking into account gender.

Table 1. The intensity of components of emotional burnout of law enforcement officials depending on gender

\begin{tabular}{|l|c|c|c|c|c|c|}
\hline \multirow{2}{*}{ Symptom } & \multicolumn{3}{|c|}{ Men } & \multicolumn{3}{c|}{ Women } \\
\cline { 2 - 7 } & $\mathbf{M}$ & $\mathbf{0}$ & Midrank & $\mathbf{M}$ & $\mathbf{0}$ & Midrank \\
\hline $\begin{array}{l}\text { Experiencing psycho- } \\
\text { traumatic circumstances }\end{array}$ & 5,2 & 3,783 & $13,04^{*}$ & 9,6 & 5,971 & $20,26^{*}$ \\
\hline $\begin{array}{l}\text { Dissatisfaction with } \\
\text { yourself }\end{array}$ & 4,3 & 4,008 & 15,50 & 6,8 & 5,549 & 18,74 \\
\hline The feeling of the "cage" & 6,5 & 6,778 & 19,31 & 5,2 & 7,436 & 16,38 \\
\hline Anxiety and depression & 5,3 & 5,978 & 16,96 & 7,0 & 9,052 & 17,83 \\
\hline
\end{tabular}

${ }^{17}$ N. UYGUÇ, "Gender, personal values and choice of profession," D.E. U.I.I.I.B.F Journal (2003), 18(1): 93-103.

${ }^{18}$ M. Moya, F. Expósito \& J. Ruiz, "Close relationships, gender, and career salience," Sex Roles (2010), 42 (9-10), 825-846.

${ }^{19} \mathrm{~S}$. THEBAUD, "Gender and entrepreneurship as a career choice do self-assessments of ability matter?" Social Psychology Quarterly (2010), 73(3): 288-304, https://doi.org/10.1177/01902725 10377882.

${ }^{20}$ V.V. BoJKO, Sindrom «emotsyonalnogo vyhoranyia» $v$ professyonalnom obshchenii. 


\begin{tabular}{|l|c|c|c|c|c|c|}
\hline $\begin{array}{l}\text { Inadequate emotional } \\
\text { selective response }\end{array}$ & 20,5 & 4,371 & 21,08 & 16,4 & 7,427 & 15,29 \\
\hline $\begin{array}{l}\text { Emotional and moral } \\
\text { disorientation }\end{array}$ & 12,3 & 5,073 & 18,73 & 10,9 & 5,703 & 16,74 \\
\hline $\begin{array}{l}\text { Expanding the sphere of } \\
\text { saving emotions }\end{array}$ & 4,8 & 4,776 & 16,42 & 7,4 & 9,223 & 18,17 \\
\hline $\begin{array}{l}\text { Reduction of professional } \\
\text { responsibilities }\end{array}$ & 14,2 & 7,247 & 18,42 & 13,2 & 8,660 & 16,93 \\
\hline Emotional deficit & 10,7 & 7,273 & 17,08 & 10,8 & 6,954 & 17,76 \\
\hline Emotional distance & 9,7 & 6,713 & 15,23 & 11,3 & 6,288 & 18,90 \\
\hline $\begin{array}{l}\text { Personal distance } \\
\text { depersonalization) }\end{array}$ & 5,8 & 6,479 & 16,42 & 7,3 & 7,780 & 18,17 \\
\hline $\begin{array}{l}\text { Psychosomatic and } \\
\text { psycho-autonomic } \\
\text { disorders }\end{array}$ & 4,6 & 2,931 & 15,23 & 8,1 & 8,402 & 18,90 \\
\hline
\end{tabular}

*significance $\mathrm{p} \leq 0,05$ according to Mann-Whitney U-test

As we can see from the table, the respondents mostly have symptomatic of inadequate emotional selective response, which is generally formed in women respondents, but especially in men. This symptom is a clear sign of professional burnout. The professional stops feeling the difference between two fundamentally different phenomena - between economic expression of emotions (which is a useful skill) and inadequate emotional selective response, which is expressed in hard-heartedness, rudeness and indifference. ${ }^{21}$ Symptoms such as "emotional distance," "emotional deficiency," "emotional-moral disorientation" and "reduction of professional responsibilities" are also expressed in the respondents at a considerable level, and they are in the formation stage.

The comparison of male and female respondents shows that, in general, women are more likely to have symptoms of burnout. In particular, significant differences were received on the indicator of "experiencing psychotraumatic circumstances" ( $p<0.05)$, which shows greater emotional vulnerability of women. But male-lawyers have some symptoms, which have reached a greater level and have already become dominant and it even requires special psychological interventions.

The results of the survey of lawyers regarding gender stereotypes and manifestations of gender inequality in the professional sphere are given in table 2 .

\footnotetext{
${ }^{21}$ Ibidem.
} 
Table 2. Responses of lawyers about gender stereotypes and gender inequalities in the profession

\begin{tabular}{|c|c|c|c|c|}
\hline \multirow{2}{*}{\multicolumn{2}{|c|}{ Questions }} & \multicolumn{2}{|c|}{ Gender } & \multirow{2}{*}{$\begin{array}{l}\text { Significance of } \\
\text { differences, } \chi^{2}\end{array}$} \\
\hline & & \multirow{2}{*}{\begin{tabular}{|r|} 
Women, $\%$ \\
66,7
\end{tabular}} & \multirow{2}{*}{$\begin{array}{r}\text { Men, \% } \\
100,0\end{array}$} & \\
\hline \multirow{2}{*}{$\begin{array}{l}\text { Have you ever felt biased attitude at your } \\
\text { working place due to your gender? }\end{array}$} & no & & & \multirow[b]{2}{*}{0,021} \\
\hline & yes & 33,3 & & \\
\hline \multicolumn{2}{|r|}{ Total } & $100,0 \%$ & $100,0 \%$ & \\
\hline \multirow{2}{*}{$\begin{array}{l}\text { In your point of view, can the gender influence } \\
\text { any business success? }\end{array}$} & no & $57,1 \%$ & $76,9 \%$ & \multirow[t]{2}{*}{,248 } \\
\hline & yes & $42,9 \%$ & $23,1 \%$ & \\
\hline \multicolumn{2}{|r|}{ Total } & $100,0 \%$ & $100,0 \%$ & \\
\hline \multirow{2}{*}{$\begin{array}{l}\text { Did you feel any biased attitude from your } \\
\text { management when they were evaluating your } \\
\text { work, due to your gender?? }\end{array}$} & no & $85,7 \%$ & $100,0 \%$ & \multirow[t]{2}{*}{, 160} \\
\hline & yes & $14,3 \%$ & & \\
\hline \multicolumn{2}{|c|}{ Total } & $100,0 \%$ & $100,0 \%$ & \\
\hline \multirow{2}{*}{$\begin{array}{l}\text { Do you think that men and women suffer from } \\
\text { the gender stereotypes and norms that exist in } \\
\text { our society?? }\end{array}$} & no & $42,9 \%$ & $61,5 \%$ & \multirow[t]{2}{*}{,297 } \\
\hline & yes & $57,1 \%$ & $38,5 \%$ & \\
\hline \multicolumn{2}{|r|}{ Total } & $100,0 \%$ & $100,0 \%$ & \\
\hline \multirow{2}{*}{$\begin{array}{l}\text { According to your point of view, do you think } \\
\text { that men and women work with equal efficiency } \\
\text { and results. }\end{array}$} & no & $38,1 \%$ & $61,5 \%$ & \multirow[t]{2}{*}{190} \\
\hline & yes & $61,9 \%$ & $38,5 \%$ & \\
\hline \multicolumn{2}{|r|}{ Total } & $100,0 \%$ & $100,0 \%$ & \\
\hline
\end{tabular}

As we can see from the Table 2, the survey results indicate that one third of women $(33.3 \%)$, they have personally felt biased attitude due to their gender; however, none of the men felt biased attitude (differences are significant, at the level $\mathrm{p}<0.05$ ). There were no statistically significant differences in other response, but the significant difference in answers indicates that gender inequalities in professional activity are relevant for women, while most male respondents take the situation as normal and, sometimes they then even support these stereotypes. Especially this can be seen by answering the question of whether men and women work with equal efficiency and effec- 
tiveness: the majority of male respondents (61.5\%) answered negatively, while most female respondents tend to think that work efficiency does not depend on gender.

Thus, the survey showed that women working in the field of law are influenced by gender stereotypes. It can be expressed in a biased attitude, different opportunities for success for male and female and evaluation of the efficiency and effectiveness of their work. Despite the fact that most male respondents deny the existence of gender inequality in the profession, but significant differences between men's and women's responses to the question concerning biased attitude, as well as differences in answers to other questions, indicate a real problem. In conclusion, we can say that gender inequality in professional sphere can be an additional stress factor for women. It can affect their professional self-realization, well-being, as well as it can be one of the factors of career crisis.

\section{DISCUSSION}

The data, which we have received on the specifics of the career crisis of representatives of the legal profession, correspond with the results of current researches. In particular, in the study of professional burnout syndrome in police officers, such scientists as Borysiuk O.M, Fostiak M.V. have found out that $24 \%$ of respondents had the syndrome at the stage of formation, and in $9 \%$ of respondents it was already formed. ${ }^{22}$

In the field of studying gender stereotypes and gender inequality as an additional factor in women's occupational crisis there are also some interesting researches. In these researches the general tendencies for different professions in the labor market of different countries are characterized. For example, in Poland, it is often said about discrimination against women in the labor market. It is expressed in unequal treatment of women and men who have similar levels of education, qualifications and abilities. ${ }^{23}$ On the other hand, M. Chuchra and Y. Gorbaniuk have already made some researches on attitudes towards work. They have found mostly common features both in men and women, including their attempts to reconcile professional activities

\footnotetext{
${ }^{22}$ O.M. BORYSIUK, M.V. FOSTIAK, "Doslidzhennia syndromu profesiinoho vyhorannia u pratsivnykiv natsionalnoi politsii Ukrainy," Naukovyi visnyk Lvivskoho derzhavnoho universytetu vnutrishnikh sprav (2016), 2: 102-112, http://www2.lvduvs.edu.ua/documents_pdf/visnyky/nvsp/ 02_2016/13.pdf.

${ }^{23}$ Kobiety i mężczyzni na rynku pracy (Warszawa: GUS, 2014), 2.
} 
with family responsibilities. At the same time, it was found that the perception of work as a source of constant stress is significantly more prevalent in male respondents, whereas women are more likely to treat work as a specific commitment and they do not think that it is a source of stress for them. ${ }^{24}$

In the Conney J.A.Beck, Bruce D.Sales, G.Andrew H.Benjamin research it is stated that the symptoms of stress are equally common for male and women lawyers. ${ }^{25}$ Of course, there are some gender differences, but in general, there is considerable commonalities regarding the stressors and psychological problems experienced by legal practitioners.

Both women and men had stress symptoms that far exceeded the norm and were associated with such consequences as: obsession-compulsiveness, social alienation and isolation, interpersonal sensitivity, anxiety and depression. Male lawyers reported about a significant level of stress and anger, combined with an existing sense of dissatisfaction about important personal relationships. But women lawyers have showed even a greater level of stress and anger, and also a sense of dissatisfaction with their relationship. Surveys showed that nearly $70 \%$ of lawyers could potentially have alcohol problems during their legal careers due to professional stress.

Significant gender differences in the level of stress of lawyers were discovered in the research by Patel Kriti, Rajderkar Shekar, Naik Jayashree D. Researchers found that women lawyers were more likely to experience burnout and stress than men; and the pleasure of work for women lawyers is inversely related to emotional exhaustion, workload, reduction of personal achievement, stress, jealousy, extra expectation, impersonation, strained interpersonal relationships, poor social status, competition. ${ }^{26}$

M. Gachter and staff studied the impact of gender on stress levels, taking into account both physiological and psychological indicators. No significant difference was found between men and women in physiological stress, however, female officers were found to have higher levels of physical stress (which included somatization and general health). It was found that male

${ }^{24}$ M. Chuchra, J. GorbaniuK, "Znaczenie pracy zawodowej w zyciu kobiet i mężczyzn," Roczniki Teologiczne (2017), 64, 1; DOI: http://dx.doi.org/10.18290/rt.2017.64.1-12.

25 J.A. Beck Connie, D. Sales Bruce \& G. Andrew, H. Benjamin, "Lawyer Distress: Alcohol-Related Problems and Other Psychological Concerns among a Sample of Practicing Lawyers," Journal of Law and Health (1995).

${ }^{26}$ P. KRITI, R. SHEKAR, N. JAYASHREE, "Occupational stress and burnouts as predictors of job satisfaction amongst lawyers in district Sangli," National Journal of Medical Research (2012), 2, 2: 141-144, https://www.researchgate.net/publication/267827776_Occupational_Stress_and_Burnouts _as_Predictors_of_Job_Satisfaction_Amongst_Lawyers_in_District_Sangli. 
officers were positively affected by stress reduction factors but these measures did not help to reduce the physical strain of female officers. ${ }^{27} \mathrm{We}$ totally agree with the view of researchers that a specific program should be created. It should be focused on overcoming gender stereotypes generally and at work.

Thus, the results of the studies correspond with our data regarding the presence of gender stereotypes in professional legal practice, which is a significant factor of the stress of women lawyers. At the same time, the research data are not free from doubt, so this problem requires more detailed study. Also there should be further development of implementation of measures, aimed at ensuring gender equality, as well as special measures on psychoeducation and psychosocial assistance to lawyers.

\section{CONCLUSIONS}

Career crises are an integral and important factor in personal professional activity. They can be defined as abrupt changes in the professional development, occurring at different stages of the professional life of the individual, especially during moving from one stage of professional development to another.

The professional activity of legal professionals is associated with high social responsibility, normativity, riskiness, emotional tension. All these require a constant concentration and ability to overcome stress and it can cause career crises. Career crises of representatives of these professions are mostly caused by social factors (high social responsibility, working conditions), psychosocial factors (social expectations and stereotypes, relations with colleagues) and, of course, by individual-psychological factors and specificity of professional activity.

The research has shown that professional burnout is one of the manifestations of the professional crisis of legal professionals. It can lead to emotional exhaustion, demotivation, and reduced productivity. It is revealed that among the indicators of emotional burnout among women, the experience of psycho-traumatic circumstances prevails. At the same time men have inadequate emotional selective response as the leading manifestation of emotional burnout. The indicators of reduction of professional duties and emotional

${ }^{27}$ M. Gächter, D.A. SAVAge \& B. Torgler, "Gender Variations of Physiological and Psychological Stress Among Police Officers (October 2, 2009)," Available at SSRN, https://ssrn.com /abstract=1498187 or http://dx.doi.org/10.2139/ssrn.1498187. 
distancing are also significant. It was found out that gender stereotypes can be a factor of the career crisis among women lawyers. The mentioned stereotypes are often expressed in a biased attitude, limited career opportunities and lower wages.

It is proved that one of the important scientific and practical problems is the preservation of the mental health of legal professionals, in particular, the development of special measures to prevent and overcome career crises, and the implementation of measures aimed at ensuring gender equality in the legal sphere.

\section{BIBLIOGRAPHY}

Beck Connie, J.A., Sales Bruce, D. \& Benjamin, G., Andrew, H. "Lawyer Distress: AlcoholRelated Problems and Other Psychological Concerns among a Sample of Practicing Lawyers." Journal of Law and Health (1995). Cleveland state university. https://pdfs. semanticscholar. org/a53c/caac05214a0eb7a93da70f25fedbbf4a0de0.pdf

Bulatevych, N. "Teacher's burnout syndrome: the phenomenology of the process." Polish Journal of Public Health (2017), 127(2): 62-66.

Chuchra, M., Gorbaniuk, J. “Znaczenie pracy zawodowej w życiu kobiet i mężczyzn.” Roczniki Teologiczne (2017), 64, 1. DOI:http://dx.doi.org/10.18290/rt.2017.64.1-12.

DOHERTy, J. Women's Representation in Judiciaries Worldwide: Arguments in Favor of Increasing the Gender Diversity on the Bench, (2012). http://www.gwu.edu/ ggi/assets/docs/igis _wp2_ggp_wp1_doherty.pdf.

FeEnAn, D. "Women Judges: Gendering Judging, Justifying Diversity." Journal of Law and Society (2008), 35, 4: 490-519. https://www.jstor.org/stable/40206863?seq=1\#page_scan_tab_ contents.

Gächter, M., SAvage, D.A., \& Torgler, B. "Gender Variations of Physiological and Psychological Stress Among Police Officers (October 2, 2009).” Available at SSRN: https://ssrn. com/abstract=1498187 or http://dx.doi.org/10.2139/ssrn.1498187.

Gender and Judging. Ed. by Ulrike Schultz and Gisela Shaw, 2013.

Kobiety i mężczyźni na rynku pracy. Warszawa: GUS, 2014.

Moya, M., Expósito, F., \& Ruiz, J. “Close relationships, gender, and career salience.” Sex Roles (2010), 42(9-10), 825-846.

KRITI, P., SHEKAR, R., JAYASHREE, N. "Occupational stress and burnouts as predictors of job satisfaction amongst lawyers in district Sangli." National Journal of Medical Research (2012), 2, 2 : 141-144. https://www.researchgate.net/publication/267827776_Occupational_Stress_and_Burnouts _as_Predictors_of_Job_Satisfaction_Amongst_Lawyers_in_District_Sangli.

RACKLEY, E. Women, Judging and the Judiciary: From Difference to Diversity. Routledge-Cavendish, 2012.

THEBAUD, S. "Gender and entrepreneurship as a career choice do self-assessments of ability matter?” Social Psychology Quarterly (2010), 73(3): 288-304. https://doi.org/10.1177/01902 72510377882 . 
UyGuÇ, N. "Gender, personal values and choice of profession." D.E. U.I.I.I.B.F Journal (2003), 18(1): 93-103.

Бойко, В.В. “Синдром «эмоционального выгорания» в профессиональном общении. 2-е изд. СПб.: Сударыня, 2001. [Војко, V.V. Sindrom «emotsyonalnogo vygoranyia» v professyonalnom obshchenii. 2-e izd. SPb.: Sudarynia, 2001.

Борисюк, О.М., ФОстяк, М.В. Дослідження синдрому професійного вигорання у працівників національної поліції України." Науковий вісник Львівського державного університету внутрішніх справ (2016), 2: 102-112. [BORYSIUK, O.M., FostiAK, M.V. "Doslidzhennia syndromu profesiinoho vyhorannia u pratsivnykiv natsionalnoi politsii Ukrainy." Naukovyi visnyk Lvivskoho derzhavnoho universytetu vnutrishnikh sprav (2016), 2: 102-112]. http://www2. lvduvs.edu.ua/documents_pdf/visnyky/nvsp/02_2016/13.pdf.

БРИзГАЛов, І.В. Юридична деонтологія: короткий курс лекиій. К.: МАУП, 2003. 3-те вид., стереотип. 48 с. [BRYZGHALOV, I.V. Yurydychna deontolohiia: korotkyi kurs lektsii. K.: MAUP, 2003. 3-te vyd., stereotyp. 48 s.].

БУРЛАчук, Л.Ф. Психология жизненных ситуаиий. М.: PПА, 1998. [BURLACHUK, L.F., KoRZHOVA, E.Yu. Psyholohyia zhyznennykh sytuatsij. M.: RPA, 1998].

ЗАІКА, В.М. “Динамічна модель особистісних трансформацій в умовах подолання кризових станів особистості." Соціальна психологія (2009), 1: 69-76 [ZAIKA, V.M. "Dynamichna model' osobystisnyh transformatsii v umovah podolannia kryzovykh staniv osobystosti." Sotsialna psykholohiia (2009), 1: 69-76].

ЗЕеР, Э.Ф. Психология профессий: учеб. пособие. 3-е изд., перераб. и доп. М.: Академический Проект, Фонд «Мир», 2005. [ZEER, E.F. Psyholohyia professyi: uchebn. posobye. 3e izd., pererab. i dop. M.: Akademicheskyi Proekt, Fond «Mir», 2005].

Климов, Е.А. Психология профессионала. М.: Институт практической психологии; Воронеж: МОДЭК, 1996. [KLIMOV, Y.A. Psyhologia professionala. M.: Instytut prakticheskoi psykholohii; Voronezh : MODEK, 1996].

Кон, И.С. “Постоянство и изменчивость личности.” Психологический журнал (1987), 8, 4: 126-137. [KON, I.S. "Postojanstvo i izmenchivost' lichnosti." Psiholohycheskij zhurnal (1987), 8, 4: 126-137].

Про Національну поліцію України: Закон України від 02 липня 2015 року № 580-VIII. Відомості Верховної Ради Украйни (2015), 40-41: 379. Редакція від 05.10.2016. [Рrо Natsionalnu politsiiu Ukrainy: Zakon Ukrainy vid 02 lypnia 2015 roku № 580-VIII. Vidomosti Verkhovnoi Rady Ukrainy (2015), 40-41: 379. Redaktsiia vid 05.10.2016].

Романов, В.В. Юридическая психология: учеб. для юридических специальностей ВУЗов. M.: Юрист, 2009. [Romanov, V.V. Yurydycheskaia psykholohyia. Uchebnyk dlia yurydycheskykh spetsyalnostei VUZov. M.: Yuryst, 2009].

Ряшко, О.В. “Жінка в міліцейському однострої (соціально-правовий аспект).” Наук. вісник Львівського держ. ун-ту внутрішніх справ (2008), 1-7 [RIASHкO, O.V. "Zhinka v militseiskomu odnostroi (sotsialno-pravovyi aspekt)." Naukovyi visnyk Lvivskoho derzhavnoho universytetu vnutrishnikh sprav (2008), 3: 1-7] http://www2.lvduvs.edu.ua/documents_pdf /visnyky/nvsy/03_2008/08rovosa.pdf.

Скорик, М.М. Гендерна дискриміначія у доступі до праиі й послуг: оиінка стану впровадження Украӥною антидискримінаційних Директив Ради ЄС. Аналітичне дослідження. Київ: Бюро соціальних та політичних розробок, 2017. [SKORYк, M.M. Henderna dyskryminatsiia u dostupi do pratsi y posluh: otsinka stanu vprovadzhennia Ukrainoiu anty- 
dyskryminatsiinykh Dyrektyv Rady YeS. Analitychne doslidzhennia. Kyiv: Biuro sotsialnykh ta politychnykh rozrobok (2017)] https://bureau.in.ua/downloads/2017\%20IRF\%20 Project_.pdf.

ЧЕрнухА, Н.М., РижикОВ, В.С. “Професійна діяльність юриста: теоретичні засади.” Трипільська ицивілізачія (2012), 7: 45-48. [ChERNUKha N.M., RYZhyкоV V.S. "Profesiina diialnist' jurysta: teoretychni zasady." Trypil'ska tsyvilizatsija (2012), 7: 45-48].

Юрчик, Г.М. “Дискримінація на ринку праці: прояви, вітчизняний і європейський досвід подолання.” Соціально-трудові відносини: теорія і практика: зб. наук. пр. М-во освіти і науки України; ДВНЗ «Київ. нац. екон. ун-т ім.В. Гетьмана»; Ін-т соц.-труд. відносин; редкол.: А.М. Колот (голова). Київ: КНЕУ (2016), 2: 118-128. [YURCHYK, H.M. "Dyskryminatsiia na rynku pratsi: proiavy, vitchyznianyi i yevropeiskyi dosvid podolannia." Sotsialnotrudovi vidnosyny: teoriia i praktyka: zb. nauk. pr. M-vo osvity i nauky Ukrainy; DVNZ «Kyiv. nats. ekon. un-t im. V. Hetmana»; In-t sots.-trud. vidnosyn; redkol.: A.M. Kolot (holova). Kyiv: KNEU (2016), 2: 118-128].

\section{SPECYFIKA KRYZYSU ZAWODOWEGO WŚRÓD PRAWNIKÓW: ASPEKTY PSYCHOLOGICZNE I SPOŁECZNE}

\section{STRESZCZENIE}

Artykuł dotyczy zjawiska kryzysu zawodowego u prawników. Badane jest wypalenie emocjonalne $\mathrm{z}$ podkreśleniem znaczenia wykrywania i psychokorekcji tego zjawiska. We współczesnych, demokratycznych krajach rozwiniętych jednym z priorytetów jest zapewnienie wysokiego standardu pracy i ochrony socjalnej. Z tego względu badania nad zjawiskiem kryzysu zawodowego mogą przyczynić się do poprawy warunków pracy i rozwoju zawodowego.

Życie zawodowe jest integralnym elementem ludzkiego życia, jednym z istotnych kierunków rozwoju osobowości, a także szczególną formą socjalizacji. Specyfika kariery prawniczej związana jest z wysoką odpowiedzialnością społeczną, normatywnością i dużą liczbą sytuacji konfliktowych i stresujących. Trudne warunki pracy zawodowej wpływają na stan psychiczny pracowników, co może wywoływać stres i wypalenie emocjonalne, a nawet kryzys zawodowy.

$\mathrm{Na}$ podstawie badań empirycznych ujawnione zostały czynniki społeczne i psychologiczne mające wpływ na występowanie kryzysu zawodowego w zawodach prawniczych, szczególnie poziom wypalenia emocjonalnego. Przeanalizowano cechy i symptomy wypalenia emocjonalnego u prawników obojga płci, a także rolę stereotypów związanych z płcią. Analizie poddano także rolę takich stereotypów w życiu zawodowym, co jest czynnikiem istotnie wpływającym na kryzys zawodowy u kobiet. Podkreślono znaczenie działań zapobiegających kryzysowi zawodowemu w zawodach prawniczych.

Słowa kluczowe: kryzys zawodowy; wypalenie emocjonalne; zawody prawnicze; psychokorekcja; wsparcie społeczne; profilaktyka. 